\title{
Géraldine Leroy, Batailles d'écrivains. Littérature et politique, 1870-1914
}

\section{Bertrand Marquer}

\section{(2) OpenEdition}

10 Journals

\section{Édition électronique}

URL : http://journals.openedition.org/studifrancesi/35027

DOI : 10.4000/studifrancesi.35027

ISSN : 2421-5856

Éditeur

Rosenberg \& Sellier

\section{Édition imprimée}

Date de publication : 1 novembre 2005

Pagination : 440-441

ISSN : 0039-2944

\section{Référence électronique}

Bertrand Marquer, « Géraldine Leroy, Batailles d'écrivains. Littérature et politique, 1870-1914 », Studi

Francesi [En ligne], 146 (XLIX | II) | 2005, mis en ligne le 30 novembre 2015, consulté le 18 avril 2021.

URL : http://journals.openedition.org/studifrancesi/35027 ; DOI : https://doi.org/10.4000/

studifrancesi.35027

Ce document a été généré automatiquement le 18 avril 2021.

\section{(c)}

Studi Francesi è distribuita con Licenza Creative Commons Attribuzione - Non commerciale - Non opere derivate 4.0 Internazionale. 


\title{
Géraldine Leroy, Batailles d'écrivains. Littérature et politique, 1870-1914
}

\author{
Bertrand Marquer
}

\section{RÉFÉRENCE}

GÉRALDINE LEROY, Batailles d'écrivains. Littérature et politique, 1870-1914, Paris, Armand Colin, 2003, pp. 346

Géraldine LEROY étudie les interférences entre littérature et politique au moment où l'engagement politique est en passe de devenir une composante obligée du statut de l'«intellectuel». Plutôt que de choisir une répartition par monographies d'écrivains, l'auteure a privilégié une approche axée sur les grands thèmes et événements ayant fait débat et obligés les écrivains à prendre position. Puisque la période étudiée s'ouvre par la défaite française de 1870 et se ferme sur l'entrée de la France dans la première guerre mondiale, la vision de l'Allemagne encadre l'analyse, soulignant le passage d'une perception encore tributaire de madame de Staël et de l'idéalisme philosophique introduit par Victor Cousin à une véritable hantise de l'Allemagne, modèle d'une nation forte et conquérante, mais exempte de dimension artistique. Entre ces deux images de l'Allemagne, l'auteure étudie les images de la Commune, presque intégralement excepté Victor Hugo - négatives et horrifiées, à partir d'une étude du discours générationnel des écrivains $(1830,1850,1870)$. Puis Géraldine LERoY analyse le moment fondateur de l'affaire Dreyfus, en insistant sur les précurseurs d'Émile Zola comme Bernard Lazare, puis en proposant les itinéraires croisés de trois dreyfusistes (Charles Péguy, Octave Mirbeau, Julien Benda) et de trois antidreyfusistes (Maurice Barrès, Ferdinand Brunetière, Charles Maurras) afin de souligner la diversité des parcours idéologiques au sein même des deux camps. La question du choix du régime pour la France au sortir de la défaite de 1870 est l'occasion de confronter trois positions exemplaires: le néo-royalisme de Maurras, la République populiste de Barrès et la mystique républicaine de Péguy. L'analyse de l'opposition entre «monde moderne» (les positivistes, scientistes et nationalistes) et «pays de mission» (les partisans d'un 
renouveau spirituel) fait la genèse de l'État laïc et des joutes littéraires qui l'ont accompagnée (Anatole France, Charles Maurras et Charles Péguy, principalement). La question du prolétariat permet de confronter les solutions proposées: socialisme pour Charles Péguy, retour à la terre avec René Bazin, solution catholique chez Paul Bourget, et «tentation ouvriériste» pour l'Action française, qui entendait profiter du développement d'un sentiment antidémocrate dans les rangs du mouvement syndical. La colonisation permet de revenir sur la perception de l'humanité qu'elle sous-tend: une bipartition entre «peuples forts» et "peuples faibles», les premiers apportant aux seconds le progrès, et renouvelant par là-même leur vieille civilisation menacée de décadence, renouvellement d'autant plus pressant que l'imminence d'une guerre se fait plus palpable. Dans ce domaine, si Alphonse Daudet se moque du roman colonial, tandis que Pierre Loti fait preuve d'un exotisme volontiers critique à l'égard des conquêtes coloniales, ou que Maupassant devient reporter en Algérie pour dénoncer les abus perpétrés par les colons, le constat est globalement le même: après la critique des exactions vient le temps de leur justification, au nom justement de leur succès. Le partipris de cet «ouvrage de synthèse» permet ainsi d'exposer les oppositions entre écrivains, mais également et surtout la complexité, voire les contradictions, de l'engagement des écrivains eux-mêmes, dont la «modernité» de l'engagement social peut être ainsi nuancée, soit parce qu'elle ne s'applique qu' à certaines questions, soit, tout simplement, parce que l'analyse des œuvres ou des discours met en garde contre une lecture anachronique de cette «modernité». 